\title{
Creating a Still-Life Out of Dynamic ObJects: Rights Reductionism at The Supreme Court of Canada
}

\section{LEONARD I. ROTMAN ${ }^{*}$}

In light of the fact that a significant number of Aboriginal rights decisions have recently been rendered by the Supreme Court of Canada, it is both appropriate and timely that this special issue of the Alberta Law Review focusing on Aboriginal and treaty rights issues has been published. In April 1996, the Supreme Court handed down decisions in the Badger, ${ }^{1}$ Lewis, ${ }^{2}$ and $\mathrm{Nikal}^{3}$ cases. The Court quickly followed with the Van der Peet trilogy $-R$. v. Van der Peet, ${ }^{4} R$. v. Gladstone, ${ }^{5}$ and $R$. v. N.T.C. Smokehouse Ltd. ${ }^{6}$ - and R. v. Pamajewon ${ }^{7}$ in August, and the Adams ${ }^{8}$ and Cotté decisions in October 1996. After a brief lull, the Court followed with Goodswimmer ${ }^{10}$ in February 1997, the Opetchesaht" case in May, and St. Mary's Indian Band v. Cranbrook $\left(\right.$ City) ${ }^{12}$ this past June. Meanwhile, the Court's judgment in the muchanticipated Delgamuukw $w^{13}$ case, which was heard this summer by the Supreme Court, awaits release. The long-term effects of these decisions remain to be seen. However, one discernable trend that is immediately apparent from these decisions is a return to restrictive interpretations of Aboriginal and treaty rights.

After years of restrictive interpretations, it appeared as if the Canadian judiciary's approach to Aboriginal and treaty rights was being loosened following the constitutionalization of those rights in s. 35(1) of the Constitution Act, 1982. ${ }^{14}$ Decisions like Guerin v. $R,{ }^{15}$ which gave judicial sanction to the existence of CrownNative fiduciary relations, and $R$. v. Sparrow, ${ }^{16}$ which placed those relations directly within s. 35(1), suggested that the judiciary would follow through on the promise of $s$. 35(1) as a fresh start for Canadian Aboriginal rights jurisprudence. ${ }^{17}$ However, with the

Assistant Professor, Faculty of Law, University of Alberta. Guest Editor, (1997) 36:1 Alta. L. Rev. (Symposium on Aboriginal Legal Issues).

R. v. Badger, [1996] 1 S.C.R. 771.

$R$ v. Lewis, [1996] 1 S.C.R. 921.

$R$ v. Nikal, [1996] 1 S.C.R. 1013.

[1996] 2 S.C.R. 507 [hereinafter Van der Peet].

[1996] 2 S.C.R. 723 [hereinafter Gladstone].

[1996] I S.C.R. 672.

[1996] 2 S.C.R. 821 [hereinafter Pamajewon].

$R$ v. Adams, [1996] 3 S.C.R. 101.

R. v. Côté, [1996] 3 S.C.R. 139.

Goodswimmer v. Canada (Minister of Indian Affairs and Northern Development), [1997] 1 S.C.R. 309.

Opetchesaht Indian Band v. Canada, [1997] 2 S.C.R. 119.

St. Mary's Indian Band v. Cranbrook (City) (1997), 147 D.L.R. (4th) 385 (S.C.C.).

Delgamuukw v. British Columbia, [1994] 1 S.C.R. vi.

Schedule B to the Canada Act 1982 (U.K.), 1982, c. 11.

(1984), 13 D.L.R. (4th) 321 (S.C.C.) [hereinafter Guerin].

(1990), 70 D.L.R. (4th) 385 (S.C.C.) [hereinafter Sparrow].

Although even these decisions were plagued by certain key findings of a restrictive nature. For example, in Guerin, supra note 15, Dickson J., as he then was, found that, on the basis of the decision in Smith v. R. (1983), 147 D.L.R. (3d) 237 (S.C.C.), the Musqueam band's interest in their 
recent decisions released by the Supreme Court of Canada, in particular, the Van der Peet trilogy and Pamajewon, the Court appears to have done an about-face. Van der Peet and Gladstone, in particular, demonstrate the current Supreme Court's restrictive approach to the identification of Aboriginal rights and the manner in which those rights may be limited by government regulation.

One of the more troubling themes in contemporary Canadian Aboriginal rights jurisprudence that indicates the judiciary's return to restrictive interpretations of Aboriginal and treaty rights is the increasing judicial compartmentalization of Aboriginal issues. When dealing with claims to Aboriginal or treaty rights, for example, the courts seem intent on separating those claims from the circumstances that initially gave rise to them. By isolating these claims from their historical, cultural, social, political, and legal contexts, the courts' examinations invariably take place in a juridical vacuum. As a result of this acontextual method of analysis, the judgments that emanate from such examinations are neither sensitive to Aboriginal understandings of the nature of their rights nor representative of the true nature of the claims being raised.

The Supreme Court of Canada's decision in Pamajewon ${ }^{18}$ is a good illustration of the judicial treatment of Aboriginal issues in a contextual vacuum. In Pamajewon, the Court rejected the claimed right of the Shawanaga and Eagle Lake First Nations to regulate high-stakes gambling activities on their reserves as an incident of selfgovernment. It held that regulating high-stakes gambling was not an Aboriginal right traceable to a pre-contact practice, as required by the Court's decision in $R$ v. Van der Peet. In arriving at this decision, the Court focused on the regulation of gambling as a discrete issue rather than whether it was part of the bands' larger right of selfgovernment. Thus, the judgment was, effectively, rendered on a different issue than that advanced by the bands.

There is a significant distinction between an Aboriginal or treaty right and a practice that is derived from those rights. In Pamajewon, the power of economic selfdetermination claimed by the bands, which they translated, in part, into their ability to regulate high-stakes gambling, flowed directly from their claimed right of selfgovernment. By considering the regulation of high-stakes gambling as a distinct right, however, the Supreme Court was able to dismiss the appellants' claim by finding that such regulation was not an integral part of the distinctive cultures of either the Shawanaga or Eagle Lake First Nations prior to contact with Europeans. Lamer C.J.C.

reserve lands was not a beneficial interest sufficient to give rise to a trust relationship. Meanwhile, in Sparrow, supra note 16, the application of federal regulations to the exercise of traditional aboriginal fishing rights was predicated upon the Supreme Court's unquestioned acceptance of the Crown's sovereignty over Canada. As the Court explained at 404:

It is worth recalling that while British policy towards the native population was based on respect for their right to occupy their traditional lands, a proposition to which the Royal Proclamation of 1763 bears witness, there was from the outset never any doubt that sovereignty and legislative power, and indeed the underlying title, to such lands vested in the Crown. 
held that to characterize the appellants' activities as falling under a broad right to manage the use of their reserve lands "would be to cast the Court's inquiry at a level of excessive generality." 19

The Supreme Court's approach in Pamajewon is by no means an isolated incident. The application of the same principles that were used to compartmentalize the rights in issue in Pamajewon has had detrimental effects on other rights, such as the Aboriginal right to fish. In Van der Peet, the judiciary's consideration of the appellant's right to fish resulted in a similar reduction. That right was altered from the broad Aboriginal right initially claimed by the plaintiff at trial to the right to fish for a moderate livelihood found by the dissenting judgment of Lambert J.A. at the British Columbia Court of Appeal and, finally, to a right to fish only for food by the Supreme Court of Canada. Engaging in this form of rights reductionism allows courts to dismiss individual Aboriginal claims without having to consider the broader right being asserted. It simplifies a court's analysis in the instant case and prevents the creation of a precedent that may be looked to by other Aboriginal groups claiming a similar right. $^{20}$

By reducing broad Aboriginal and treaty rights like self-government or fishing to specific practices in cases such as Pamajewon and Van der Peet, the judiciary divorces those rights from the larger context within which they both originated and continue to exist. Such judicial activity creates an environment for culturally-inappropriate interpretations of those rights. Part of the reason for this judicial practice may be traced to the sentiment behind the Supreme Court of Canada's decision in Kruger and Manuel v. The Queen, where Dickson J., as he then was, stated that "If the claim of any Band in respect of any particular land is to be decided as a justiciable issue and not a political issue, it should be so considered on the facts pertinent to that Band and to that land, and not on any global basis." ${ }^{21}$ However, it appears as if subsequent judicial analyses of Aboriginal and treaty rights have taken Dickson J.'s dictum to an inappropriate extreme.

While the Court's statement in Kruger and Manuel warned against determining Aboriginal land entitlements without regard to the context in which a specific claim was being made, it has since been used as a basis for the courts to avoid articulating broad principles of Aboriginal and treaty rights. Such a narrow perspective entrenches the notion that contextual analysis in Canadian Aboriginal rights jurisprudence ought to be restricted to the specific rights in issue. In Van der Peet, this was translated into whether Mrs. Van der Peet had an Aboriginal right to sell fish for fifty dollars rather than whether Mrs. Van der Peet, as a member of the Sto:lo Nation, was able to sell the fish as part of a broader Aboriginal fishing right.

19 Pamajewon, supra note 7 at 834.

20 On this topic, see C. Bell, "New Directions in the Law of Aboriginal Rights" (1998) Can. Bar Rev. (forthcoming).

21 (1977), 75 D.L.R. (3d) 434 at 437 (S.C.C.) 
To place Aboriginal and treaty rights issues in a proper contextual framework, it is necessary to regard them on microscopic and macroscopic levels. On the microscopic level, consideration ought to be given both to the circumstances in which the rights in question arose and those in which they continue to exist. Such an inquiry should account for the nature of the right itself and the method of exercising it. The macroscopic level contemplates the broader, or general, history of Crown-Native relations. The modern shape of Aboriginal and especially treaty rights may be traced to historical Crown-Native interaction. ${ }^{22}$ This macroscopic level of analysis includes accounting for the fiduciary nature of the parties' interaction. Such an approach is consistent with the understanding of Aboriginal and treaty rights as dynamic, evolving rights which has been articulated by the Supreme Court of Canada in decisions such as Simon v. $R^{23}$ and Sparrow.

In Simon, a treaty hunting rights case, the Court stated that treaties between the Crown and Aboriginal peoples should "be interpreted in a flexible way that is sensitive to the evolution of changes."24 Accordingly, the Court held that the exercise of hunting rights included in an eighteenth century treaty which stated that "the said Tribe of Indians shall not be hindered from, but have free liberty of hunting and fishing as usual,"25 entailed that the hunting right was not to be restricted to the manner in which those rights were exercised at the time of the treaty. As Dickson C.J.C. explained for the Court:

I do not read the phrase "as usual" as referring to the types of weapons to be used by the Micmac and limiting them to those used in 1752. Any such construction would place upon the ability of the Micmac to hunt an unnecessary and artificial constraint out of keeping with the principle that Indian treaties should be liberally construed. ${ }^{26}$

In Sparrow, an Aboriginal fishing rights decision, the Supreme Court determined that the notion of "existing" rights in s. 35(1) of the Constitution Act, 1982 did not mean existing in their form on 17 April 1982, but included all rights in existence on that date in their complete, original form. This finding entailed that rights which had not been extinguished prior to 17 April 1982, including those rights which had been heavily regulated, were given constitutional affirmation and protection in the form they took prior to their regulation. ${ }^{27}$ The Court determined that the interpretation of $s .35(1)$ necessitated such a purposive approach:

While the contemporary exercise of aboriginal and treaty rights draws upon historical aboriginal practices related to their physical and cultural survival, it is not wedded to those practices, as the rejection of frozen rights theory in Sparrow, supra note 16, shows. See the discussion of frozen rights, infra.

(1985), 24 D.L.R. (4th) 390 (S.C.C.).

Ibid. at 403.

Ibid. at 396.

Ibid. at $402-403$.

The Court's decision in Sparrow, supra note 16, entails that in protecting "existing" aboriginal and treaty rights, s. 35(1) severed any existing regulation of those rights from the rights themselves. Thus, s. 35(1) protects rights, not their regulation. See B. Slattery, "The Constitutional Guarantee of Aboriginal and Treaty Rights" (1982-83) 8 Queen's L.J. 232 at 243, 264. 
The nature of s. 35(1) itself suggests that it be construed in a purposive way. When the purposes of the affirmation of aboriginal rights are considered, it is clear that a generous, liberal interpretation of the words in the constitutional provision is demanded. ${ }^{23}$

In both of these decisions, the Supreme Court of Canada was explicit about rejecting a "frozen rights" approach to Aboriginal and treaty rights. It recognized that Aboriginal and treaty rights are vibrant rights that cannot be restricted to their form or manner of exercise at a particular point in time. For this reason, the Court in Sparrow adopted Professor Slattery's observation that "the word 'existing' ... suggests that the rights in question are affirmed in a contemporary form rather than in their primeval simplicity and vigour."29 Meanwhile, the Court's rejection of this frozen rights approach led it to adopt Professor Lyon's explanation of the purpose and effect of s. 35(1):

[T] he context of 1982 is surely enough to tell us that this is not just a codification of the case law on aboriginal rights that had accumulated by 1982 . Section 35 calls for a just settlement for aboriginal peoples. It renounces the old rules of the game under which the Crown established courts of law and denied those courts the authority to question sovereign claims made by the Crown. ${ }^{30}$

As the Simon and Sparrow decisions indicate, rejecting the "old rules of the game" includes rejecting frozen rights theory as a method of ascertaining or describing Aboriginal and treaty rights. Yet, in more recent decisions, such as Van der Peet, the Supreme Court has demonstrated significant infidelity to the doctrine it espoused in Sparrow.

By finding that an activity could only be considered to be an Aboriginal right if it was an element of a practice, tradition, or custom integral to the distinctive culture of the Aboriginal group claiming the right and, furthermore, that it was traceable to precontact practices, Lamer C.J.C.'s majority judgment in Van der Peet effectively reanimated the frozen rights theory that had seemingly been put to rest by Simon and Sparrow. It is simply not possible to (a) indicate that Aboriginal rights may only encompass those rights that are integral to the distinctive cultures of Aboriginal peoples, yet (b) fail to recognize "new" practices that attempt to fill the void left by the effect of European settlement on traditional rights while (c) professing to reject frozen rights theory as the majority's judgment attempted to do in Van der Peet. ${ }^{31}$ As I suggested in an earlier essay:

Arbitrarily limiting the definition of Aboriginal rights to pre-contact practices prohibits the creation of new Aboriginal rights arising from the necessity to maintain the viability of distinctive Aboriginal cultures in the face of European interference with traditional Aboriginal ways of life. ${ }^{32}$

Sparrow, supra note 16 at 407.

B. Slattery, "Understanding Aboriginal Rights" (1987) 66 Can. Bar Rev. 727 at 782.

Sparrow, supra note 16 at 406, quoting N. Lyon, "An Essay on Constitutional Interpretation" (1988) 26 Osgoode Hall L.J. 95 at 100.

Supra note 4 at 556.

L.I. Rotman, "Hunting for Answers in a Strange Kettle of Fish: Unilateralism, Paternalism and Fiduciary Rhetoric in Badger and Van der Peet" (1997) 8 Constitutional Forum 40. 
If the majority judgment in Van der Peet had truly rejected frozen rights theory, it would not have placed as much emphasis on temporal considerations to ground its determination of what practices, traditions, or customs qualified as constitutionallyprotected rights under s. 35(1). Time-based considerations of Aboriginal and treaty rights focus only on limited aspects of those rights. Whether a particular practice has been exercised for 20 years or 200 years does not, in and of itself, demonstrate the importance of that practice to the cultural and physical survival of an Aboriginal group. There may be a variety of reasons why some old practices remain in existence while others disappear. Changes in technology or climate may require modification or abandonment of traditional practices. The fact of European settlement and its geographical, social, political, and economic effects is certainly one reason why some Aboriginal groups may have needed to alter traditional, pre-contact practices in order to maintain their viability as distinctive cultures. Arbitrarily establishing the date of European contact - which is, itself, a contentious issue ${ }^{33}$ - as the cut-off date for establishing constitutionally-protected Aboriginal rights fails to recognize that contact itself generated the need for Aboriginal groups to alter their lifestyles to ensure their survival in post-contact North America. Yet, as the Van der Peet test would have it, any such post-contact practice, simply because it arose after contact, is considered less important than a pre-contact practice and certainly less deserving of constitutional protection.

Insofar as Aboriginal and treaty rights are to be viewed in connection with the cultural and physical survival of Aboriginal peoples, ${ }^{34}$ judicial considerations of those rights ought to shift away from temporal considerations and towards the continued vitality of Aboriginal societies. ${ }^{35}$ Truly abandoning the old rules of the game, as suggested by the Supreme Court of Canada in Sparrow, means abandoning the judicial practice of rights reductionism that is characteristic of some of its most recent judgments. This, in turn, requires the judiciary to move away from precedents rooted in bygone eras that no longer reflect the Canadian situation. As Brennan J., as he then was, explained in his judgment in Mabo v. Queensland [No. 2]:

\begin{abstract}
Although our law is the prisoner of its history, it is not now bound by decisions of courts in the hierarchy of an Empire then concerned with the development of its colonies.... [N]o case can command unquestioning adherence if the rule it expresses seriously offends the values of justice and human rights (especially equality before the law) which are aspirations of the contemporary Australian legal system. $^{36}$
\end{abstract}

Although Mabo is an Australian case, the principles espoused by Brennan J. ought to apply equally to Canada. Indeed, Sparrow's rejection of the "old rules of the game"

It may be legitimately asked whether "contact" means the first meeting of Aboriginal and European peoples at a particular place or whether some more substantial interaction is required, such as the European establishment of a trading post or settlement.

3s For further discussion of this, and similar points, see J. Borrows \& L.I. Rotman, "The Sui Generis Nature of Aboriginal Rights: Does It Make A Difference?" (1997) 36 Alta. L. Rev. 9.

$36 \quad$ (1992) 175 C.L.R. 1 at 29-30 (H.C. Aust.). 
evince a similar sentiment. Unfortunately, recent jurisprudence suggests more of a return to these old rules than an abandonment of them.

While this symposium is not devoted to the Supreme Court's recent judgments, the articles contained herein discuss the implications of the Court's restrictive approach to Aboriginal and treaty rights that informs those judgments. In "The Sui Generis Nature of Aboriginal Rights: Does It Make A Difference?"37 John Borrows, Director of First Nations Legal Studies at the Faculty of Law, University of British Columbia and Leonard Rotman of the Faculty of Law, University of Alberta examine the ramifications of describing Aboriginal and treaty rights as sui generis. Professors Borrows and Rotman trace the development of the sui generis concept and propose a framework for understanding what a meaningful description of those rights as sui generis ought to entail. Their article seeks to provide substance to a phrase that has garnered widespread adoption, but has been largely left devoid of meaning.

James [sákéj] Youngblood Henderson, Research Director of the Native Law Centre, University of Saskatchewan carries on with this theme of "sui generis" in his article entitled "Interpreting Sui Generis Treaties." ${ }^{\text {"38 }} \mathrm{He}$ argues that the unique nature of treaties between the Crown and Aboriginal peoples requires a special method of interpretation that cannot be accomplished by focusing solely on common law understandings. As negotiated compacts between nations, Professor Henderson suggests that differences in the parties' world views and in their understanding and use of language must be accounted for in judicial considerations of treaty rights.

Patrick Macklem of the Faculty of Law, University of Toronto, considers another aspect of the unique relationship between the Crown and Aboriginal peoples in his article "Aboriginal Rights and State Obligations." ${ }^{39} \mathrm{He}$ focuses on whether the recognition of Aboriginal rights in the Canadian Constitution imposes positive obligations on government to provide economic or social benefits to Aboriginal peoples. Key elements of Professor Macklem's examination are whether Aboriginal rights are positive or negative rights and whether the Crown's fiduciary duty to Aboriginal peoples or its obligations under international law include a responsibility to provide such benefits.

In "Aboriginal Title and Aboriginal Rights: What's The Connection?" 40 Kent McNeil of Osgoode Hall Law School concentrates on the "distinctive to the integral culture" test for determining what constitutes an Aboriginal right formulated in Van der Peet and how it relates to the connection between Aboriginal rights and Aboriginal title discussed in the Adams and Coté decisions. After clarifying what this test entails, Professor McNeil considers how it might apply to an Aboriginal title claim. 
Leonard Rotman of the Faculty of Law, University of Alberta looks at the effect of recent jurisprudence on the Sparrow justificatory test in "Defining Parameters: Aboriginal Rights, Treaty Rights, and the Sparrow Justificatory Test."41 He maintains that post-Sparrow judgments have incorrectly extended the Sparrow test to treaty rights without adequately considering the significant differences between Aboriginal and treaty rights. Professor Rotman's article provides reasons why the Sparrow test ought not be mechanically applied to treaty rights and proposes an alternative framework that he suggests is more consistent with the consensual basis of Crown-Native treaties.

In "Metis Constitutional Rights in Section 35(1)," 22 Catherine Bell of the Faculty of Law, University of Alberta discusses how recent Supreme Court decisions may affect the assertion of Metis rights. Her article maintains that these decisions allow for the courts to find that Metis rights are separate and unique from other Aboriginal rights. She expresses concern that decisions such as $R$ v. Van der Peet that use European contact as a cut-off point for defining Aboriginal rights threaten Metis rights insofar as Metis culture blends European and Aboriginal elements. Professor Bell concludes that Metis rights warrant their own constitutional protection in s. 35(1).

Judicial recognition of the unique nature of Metis, Aboriginal, and treaty rights can be both a blessing and a curse. Initially, when judgments such as Guerin and Sparrow described these rights as sui generis, they were hailed as progressive. The reasoning contained in those decisions recognized that Aboriginal and treaty rights were not the same as other forms of rights and could not be properly understood simply by reference to common law conceptions. Rather, they had to be understood by using a combination of Aboriginal and common law conceptions. While these decisions paved the way for more contextually-appropriate analyses of such rights by separating them from other forms of rights, more recent decisions have demonstrated that rather than opening up new avenues of analysis, characterizing Aboriginal and treaty rights as sui generis provided a means to avoid definition. The most recent Supreme Court decisions reveal the truth of this assertion.

The articles that follow attempt to recontextualize Aboriginal and treaty rights issues by providing greater substance to those issues. In different ways, they propose means of understanding those rights and their place within Canadian society that counteracts the rights reductionism currently pervading Aboriginal rights decision-making. They serve as a warning to the judiciary that it is doing a disservice to the nature of Aboriginal and treaty rights when it places such artificial restraints upon them. One can only hope that their messages are heeded. 